\title{
SYNTHESIS AND CHARACTERISATION OF HYDROGELS BASED ON STARCH AND CITRIC ACID
}

Ljubiša Nikolić1, Tijana Stojanović ${ }^{1}, V$ esna Nikolić1, Maja Urošević1, Snežana Ilić-Stojanović ${ }^{1}$, Ana Tačić1, Ivana Gajić1, Vesna Savić2 Aleksandar Zdravković ${ }^{3}$

${ }^{1}$ Faculty of Technology, University of Niš, Leskovac, Serbia

2Department of Pharmacy, Faculty of Medicine, University of Niš, Niš, Serbia

${ }^{3}$ Academy of Professional studies South Serbia, Department of Technology and Art studies Leskovac, Leskovac, Serbia

In this study, two series of hydrogels were synthesised with different molar ratio of glucose units of starch and citric acid. The advantage of using natural raw materials (starch and citric acid) for the synthesis of hydrogels lies in the fact that these raw materials are synthesised in nature, beneficial to human beings, easily degradable after use and harmless. The generated hydrogels and starting reactants were structurally characterised by applying the method of Fourier transform infrared spectroscopy (FTIR). FTIR analysis shows that the synthesis reaction of hydrogels based on starch and citric acid rests upon the esterification reaction of carboxyl groups in citric acid with hydroxyl groups in starch. The residual amount of citric acid in synthesised hydrogels was determined under high pressure with high-performance liquid chromatography (HPLC). The values of unreacted citric acid range between 9.85 and 16.08\%. The scanning electron microscopy was applied in the analysis of hydrogel morphology. The swelling of hydrogel was monitored at $25^{\circ} \mathrm{C}$ in the solutions of $\mathrm{pH}$ values of 5,7 and 9. The highest swelling degree $(\alpha=8.55)$ was achieved in water at $\mathrm{pH} 7$ for the hydrogel synthesised with the smallest amount of citric acid as the cross-linker at the ratio of glucose units of starch and citric acid being 72 . Hydrogels synthesised from such monomers are environmentally friendly and fully biodegradable.
Keywords: biomaterial, hydrogel, starch, citric acid, swelling

\section{Introduction}

Hydrogels are three-dimensional hydrophilic networks that can be obtained by cross-linking natural or synthetic polymers. When put in water, they do not dissolve, but merely swell [1-4]. Because of their high water content, softness and biocompatibility they resemble a biological tissue $[3,4]$. Biocompatibility, biodegradability and nontoxicity of polysaccharide-based hydrogels enable their wide application in the field of biomedicine [5-7]. Polysaccharides are a natural class of polymers obtained from plants and microorganisms [7]. Starch is the primary energy reserve in higher plants and the second largest carbohydrate in biosphere, after cellulose. Since it is a biogradable polymer with well-defined chemical properties, it has enormous potential as a renewable resource $[8,9]$. Starch is composed of two kinds of polymers: amylose and amylopectin (Figure 1). Amylose is a linear molecule composed of glucose residues linked by $\alpha(1 \rightarrow 4)$ bond, whereas amylopectin is branched and, besides its basic linear chain, it has branches in $\alpha(1 \rightarrow 6)$ position. Amylose is amorphous, linear and soluble polysaccharide, whereas amylopectin is insoluble and displays a highly organised structure of densely packed double helices formed between neighbouring linear chains [9]. Crosslinking enhances the properties of biomaterials. However, it can cause undesirable changes in the biopolymer functionality. Crosslinking agents may require special conditions for application, whereupon crosslinked materials can be toxic. However, it was demonstrated that poly(carboxylic) acids, which can be crosslinked both in dry and wet conditions, enhance tightening properties, increase stability in aqueous conditions, as well as foster cell proliferation [10]. Carboxylic acids are preferred for crosslinking of proteins and cellulose because of their low toxicity, price and ability to improve desirable properties of materials [11]. Citric acid is an organic acid used in food industry [12]. It can be used as a crosslinking agent since it contains three carboxyl and one hydroxyl group (Figure1). It is nontoxic and cheap to use compared to other cross-linkers [13]. Reddy and Yang investigated the possibility of crosslinking starch films with citric acid to enhance their strength and stability. Starch films cross-linked with citric acid exhibit about $150 \%$ higher strength than noncrosslinked films, and have better strength than most crosslinked starch films and synthetic polymers [14]. Menzel et al. achieved citric acid crosslinking of starch

\footnotetext{
*Author address: Ljubiša Nikolić, Faculty of Technology, University of Niš, Bulevar Oslobođenja 124, 16000 Leskovac, Serbia.

E-mail: nljubisa@tf.ni.ac.rs; nljubisa@yahoo.com

The manuscript received: May, 04, 2020.

Paper accepted: June, 05, 2020.
} 
at the temperature of $70{ }^{\circ} \mathrm{C}$, which is estimated to be the lowest temperature so far at which any crosslinking reaction occurred, which is essentially important for the use of starch in paper industry since no high temperatures will be required for crosslinking [15]. In the study by Uliniuc et al. [16], chemically modified starch-based hydrogels crosslinked with citric acid with switchable hydrophilicity were synthesised. Hydrogels exhibit various swelling degrees depending on their composition and surrounding medium, which was used for the controlled release of Levofloxacine. Crosslinking density increases with the increase in the concentration of citric acid and crosslinking time, whereby water/drug retention decreases. The aim of this study is the synthesis and characterisation of hydrogels based on starch and citric acid.

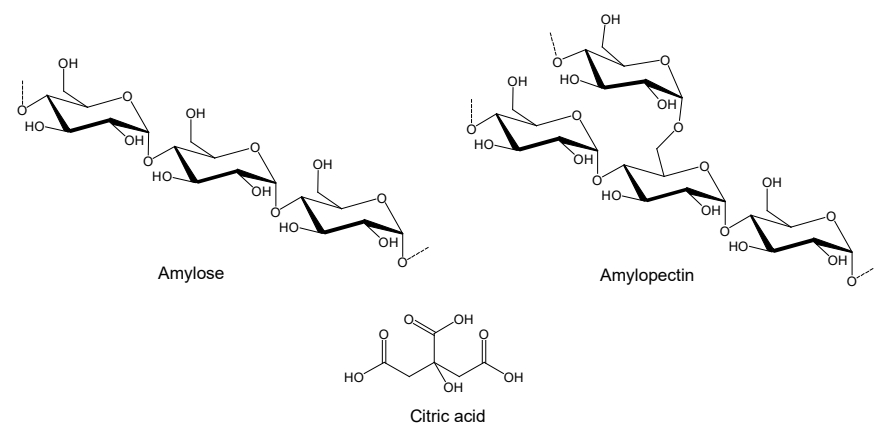

Figure 1. Structural formulas of amylose, amylopectin and citric acid

\section{Experimental}

\section{Reagents}

To synthesise hydrogels we used starch (Kemika, Zagreb, Croatia); citric acid (Moravka, Leskovac, Serbia); distilled and redistilled water (Faculty of Technology in Leskovac, Serbia); concentrated hydrochloric acid, $\mathrm{HCl}$, (Zorka Pharma-Hemija DOO, Šabac, Serbia); sodium hydroxide, $\mathrm{NaOH}$, (Zorka Pharma-Hemija DOO, Šabac, Serbia); acetonitrile (99.7\% HPLC purity, Merck KgaA, Darmstadt, Germany), potassium bromide (min 99\%, for IR spectroscopy, Merck KgaA, Darmstadt, Germany). Other reagents used in the study are of analytical grade purity.

\section{Synthesis of hydrogels}

For making hydrogels based on starch and citric acid, first the solution of starch is prepared by suspending soluble starch $(30 \mathrm{~g})$ in $50 \mathrm{~cm}^{3}$ distilled water and by adding the suspension into $150 \mathrm{~cm}^{3}$ heated distilled water $\left(70-80^{\circ} \mathrm{C}\right)$ while stirring until completely dissolved. The distilled water $250 \mathrm{~cm}^{3}$ in volume is added to the given solution. Two series of hydrogels based on starch and citric acid with different ratio of starch glucose units and citric acid are synthesised, as shown in Table 1. The first series is marked as $I_{0}-I_{3}$ (for this series of samples the starch concentration in the solution was $0.74 \mathrm{mmol} / \mathrm{cm}^{3}$ ), whereas the other series $\left\|_{4}-\right\|_{6}$ (the starch concentra- tion in the solution was $\left.0.37 \mathrm{mmol} / \mathrm{cm}^{3}\right)$. The reaction mixtures of starch and citric acid were heated for one hour at the temperature of $70-80{ }^{\circ} \mathrm{C}$, then left at the room temperature for three days, after which the generated gels were additionally dried in a dryer at $105{ }^{\circ} \mathrm{C} 72$ h. During the synthesis, the sample $I_{0}$ did not achieve the desired gel consistency and did not undergo further analyses.

Table 1. Gel sample labels, molar ratios of reactants and starch concentration in the solution for synthesis

\begin{tabular}{ccc}
\hline Gel label & $\begin{array}{c}\text { Molar ratio of glucose units of } \\
\text { starch and citric acid }\end{array}$ & $\begin{array}{c}\text { Starch concentration in } \\
\text { the solution, } \mathrm{mmol} / \mathrm{cm}^{3}\end{array}$ \\
\hline$I_{0}$ & 144 & 0.74 \\
$I_{1}$ & 72 & 0.74 \\
$I_{2}$ & 36 & 0.74 \\
$I_{3}$ & 24 & 0.74 \\
$\|_{4}$ & 18 & 0.37 \\
$\|_{5}$ & 12 & 0.37 \\
$\|_{6}$ & 6 & 0.37 \\
\hline
\end{tabular}

Fourier transform infrared spectrometry (FTIR)

FTIR spectres of synthesised hydrogel samples were recorded with the technique of thin transparent tablets with potassium bromide for spectroscopy. To make tablets, $150 \mathrm{mg} \mathrm{KBr}$ and $1 \mathrm{mg}$ of the samples ground to powder in an amalgamator (WIG-L-BVG, 31210-3A, USA) were dispensed, followed by pressing of vacuumed tablets under pressure of $200 \mathrm{MPa}$. The recordings were made in wave numbers from 4000 to $400 \mathrm{~cm}^{-1}$ on the FTIR spectrophotometer Bomem Hartmann \& Braun MB-100 series. The spectra were processed by using Win-Bomem Easy software.

\section{Swelling behavior}

Swelling of synthesised gels was monitored gravimetrically. A specific amount of gels was dipped in the solutions of $\mathrm{pH}$ value 5,7 and 9 , and the volume of the samples was measured at specific time until equilibrium was reached, i.e, until achieving a constant hydrogel volume. The aqueous media for swelling were prepared setting the $\mathrm{pH}$ values by adding the solution of sodium hydroxide or the solution of hydrochloric acid by means of $\mathrm{pH}$ metre (HI9318-HI9219, Hanna, Portugal). The swelling degree, $\alpha$, was calculated with the equation (1):

$\alpha=\frac{m-m_{0}}{m_{0}}$

where is $m_{0}$ - xerogel mass, and $m$ - mass of the swollen hydrogel at time $t$.

Analysis of residual reactants

The citric acid content in the samples of synthesised gels was determined by using the method of liquid chromatography under high pressure (HPLC). The aqueous extracts were filtered through a cellulose membrane filter $0.45 \mu \mathrm{m}$ pore size and analysed on the apparatus HPLC Agilent 1100 Series with diode-array detector, DAD 1200 
Series. The ZORBAX Eclipse XDB-C18 $(250 \times 4.6 \mathrm{~mm}$, $5 \mu \mathrm{m})$ column was set on the thermostat at $25^{\circ} \mathrm{C}$. The injected volume of the samples was $10 \mu$ l. The detection was performed at the wavelength of $205 \mathrm{~nm}$. Redistilled water was used as a mobile phase, with the mobile phase flow of $1 \mathrm{~cm}^{3} / \mathrm{min}$. The calibration curve for determining the citric acid content was constructed by preparing the series of the solution of known concentrations within the range from 0 to $0.5 \mathrm{mg} / \mathrm{cm}^{3}$.

\section{Scanning electron microscopy (SEM)}

SEM was applied in order to examine the morphology of synthesized hydrogels. Prior to recording, the samples were lyophilized in the swollen state on the lyophilizer (Freeze Dryers Rotational-Vaccum-Concentrator GAMMA 1-16 LSC, Germany), and non-lyophilized samples were recorded as well. Prior to cutting, the lyophilized samples were dipped into nitrogen in order to prevent their breaking and deformation. After treating with nitrogen, the samples were sputter coated with $(15 / 85)$ gold/ palladium alloy under vacuum in the JEOL Fine Coat JFC-1100E Ion sputter (JEOL Co., Japan). The metallised samples were recorded on the apparatus JEOL Scaning Electron Microscope JSM-5300 (JEOL. Co., Japan).

\section{Results and discussion}

Figure 2 shows the FTIR starch spectrum. Within the spectrum at about $3440 \mathrm{~cm}^{-1}$ there is a wide, complex band which is the result of $\mathrm{OH}$ group valent vibrations [17] taking part in the formation of hydrogen bonds of various strengths, as well as $\mathrm{OH}$ molecule groups of constitutional water. Less intensive bands in the region of $2980-2800 \mathrm{~cm}^{-1}$ result from $\mathrm{CH}$ valent vibrations [18] and methyl ethylene, $\mathrm{CH}_{2}$ groups. Relatively distinct, complex band in the region of $1500-1300 \mathrm{~cm}^{-1}$ is connected with the plane deformation vibrations of $\mathrm{CH}_{2}$ groups from the side $\mathrm{CH}_{2} \mathrm{OH}$ group. On the other hand, in the same IR region there are also deformation vibrations of C-O-H groups from $\mathrm{CH}_{2} \mathrm{OH}$. The strong bands in the region of $1200-1000 \mathrm{~cm}^{-1}$ are conditioned by valent vibrations of C-O groups [19], both skeletal and glycoside ones.
Figure 3 shows the FTIR spectrum of citric acid. Valent vibrations of $\mathrm{CH}$ and $\mathrm{OH}$ groups of organic acids are detected between $2800 \mathrm{~cm}^{-1}$ and $3500 \mathrm{~cm}^{-1}$. The complex absorption band in the region of $3500-3200 \mathrm{~cm}^{-1}$ originates from the valent vibrations of $\mathrm{OH}$ groups [20]. The valent vibrations of the citric acid free $\mathrm{OH}$ group yield a band with a maximum at $3495 \mathrm{~cm}^{-1}$, while valent vibrations of the $\mathrm{OH}$ groups involved in intramolecular and intermolecular hydrogen bonds are observed at $3448 \mathrm{~cm}^{-1}$ and $3293 \mathrm{~cm}^{-1}$, respectively [21]. The symmetric and asymmetric oscillations of $\mathrm{O}=\mathrm{C}-\mathrm{OH}$ groups are observed at the wave numbers $1632 \mathrm{~cm}^{-1}$ and $1392 \mathrm{~cm}^{-1}$. The valent vibrations of citric acid C-OH group yield a band at $1082 \mathrm{~cm}^{-1}$. Deformation vibrations of hydroxyl group are located at $945 \mathrm{~cm}^{-1}$, whereas $\mathrm{CH}_{2}$ group demonstrates deformation vibrations at $642 \mathrm{~cm}^{-1}$. Valent vibrations of $\mathrm{C}=\mathrm{O}$ group from acid group yield a band at about $1760 \mathrm{~cm}^{-1}$, which in the case of citric acid (Figure 3) appears at $1753 \mathrm{~cm}^{-1}$ and is in accordance with the reference data $[22,23]$. If $\mathrm{C}=\mathrm{O}$ groups are involved in the formation of hydrogen bonds or molecules are dimmerized, vibrations occur at lower frequencies, which can be observed in Figure 3 as a bond at $1714 \mathrm{~cm}^{-1}$ [23].

FTIR spectra of synthesised hydrogels are very similar. The FTIR spectrum of hydrogel $\|_{4}$ are presented in the study (Figure 4). On this FTIR spectrum, a wide peak can be seen ranging from 3000 to $3500 \mathrm{~cm}^{-1}$ with a maximum at about $3440 \mathrm{~cm}^{-1}$ which comes from the valent vibrations of $\mathrm{OH}$ groups which did not participate in the process of esterification. Namely, the synthesis reaction of gels from starch and citric acid is based on the esterification reaction of carboxyl groups of citric acid with hydroxyl groups of starch. In the gel spectre, a band appears at $1735 \mathrm{~cm}^{-1}$ originating from ester carbonyl group formed in the esterification reaction of starch and citric acid [24]. Also, there are bands ranging from 1000 $1260 \mathrm{~cm}^{-1}$, which are the result of $\mathrm{C}-\mathrm{O}$ valence vibrations. A change in the position of the absorption band of $\mathrm{C}=\mathrm{O}$ group from citric acid $\left(1753 \mathrm{~cm}^{-1}\right.$ and $\left.1714 \mathrm{~cm}^{-1}\right)$ into the band with a maximum at $1735 \mathrm{~cm}^{-1}$ (ester $\mathrm{C}=\mathrm{O}$ group) clearly indicates the reaction of the carboxyl groups of citric acid with the hydroxyl groups of starch and the formation of an ester bond.

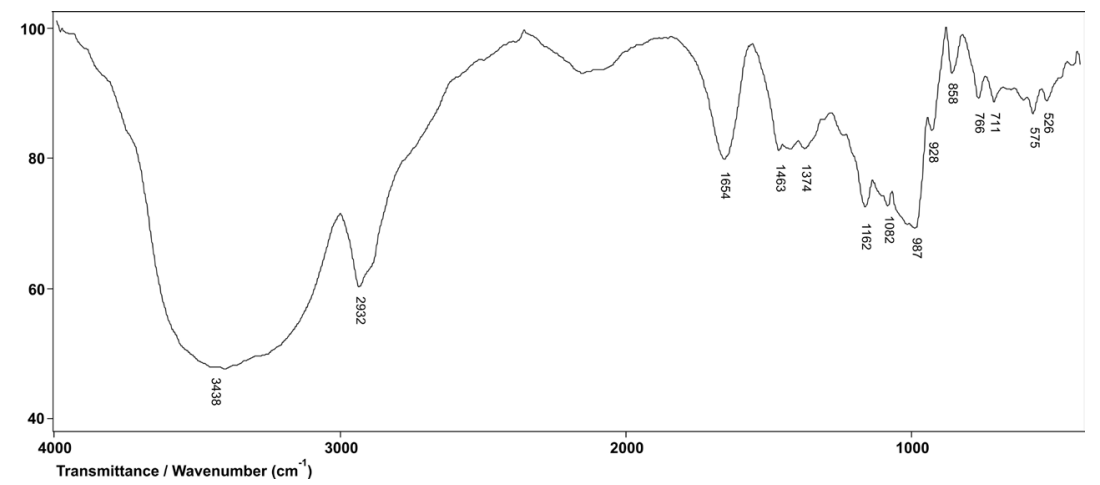

Figure 2. FTIR starch spectrum 


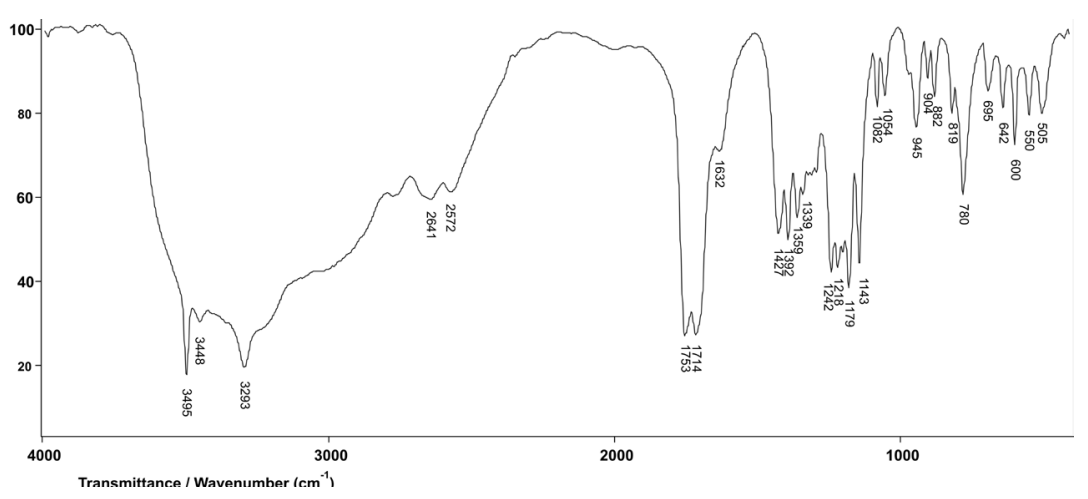

Figure 3. FTIR citric acid spectrum

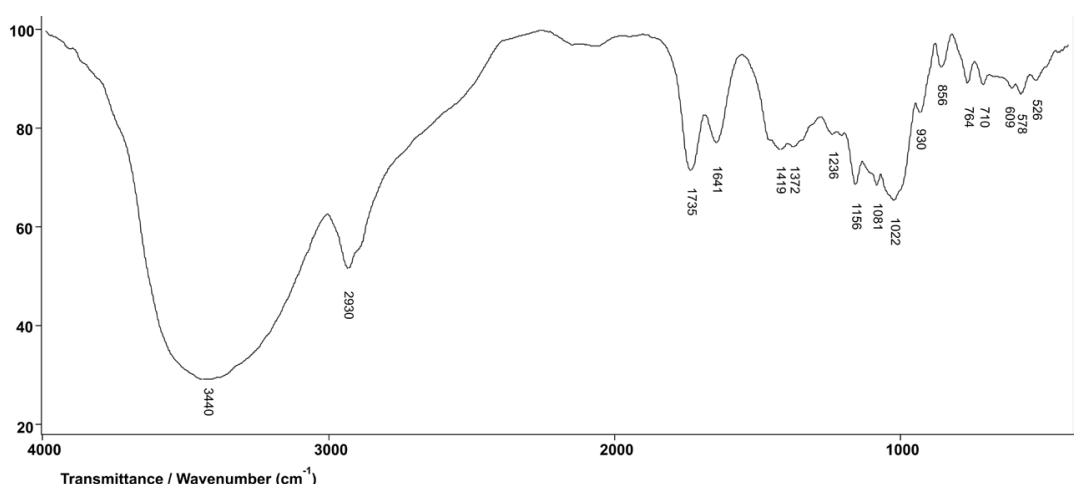

Figure 4. FTIR spectrum of gel II4 sample

On the basis of the FTIR spectra analysis and the reference data $[16,24]$, the possible gel structure is presented in Figure 5.

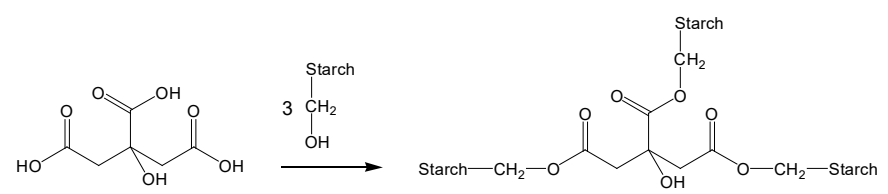

Figure 5. Possible structure of gel based on starch and citric acid

By means of the HPLC method, the aqueous extracts were analysed in order to determine unreacted amounts of citric acid. The examinations were conducted at the detection wavelength of $205 \mathrm{~nm}$. In the selected conditions of chromatography, the citric acid gives the peak in the chromatogram at the retention time $R_{t}=4.4 \mathrm{~min}$. The citric acid content in aqueous extracts is determined on the basis of the calibration standard curve of citric acid which is constructed on the basis of the known concentrations of the reactant solution and obtained peak area (A) in the HPLC chromatograms.

Figure 6 shows a HPLC chromatogram, in Figure $6 \mathrm{~b}$ the UV spectre with DAD detector as a mean value of UV spectres from each point of the peak on the HPLC chromatograms for the peak originating from citric acid. Figure 7 shows the calibration curve with the equation of a straight line for citric acid.
The unreacted amounts of citric acid during the synthesis are presented in Table 2 and range from 9.85 to $16.08 \%$.

(a)

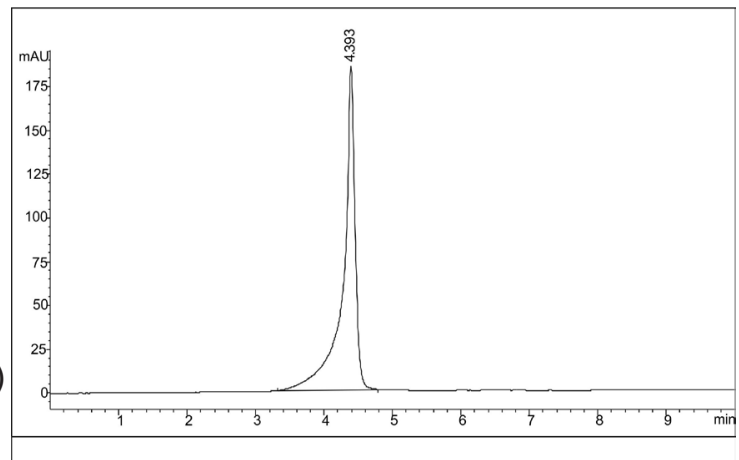

(b)

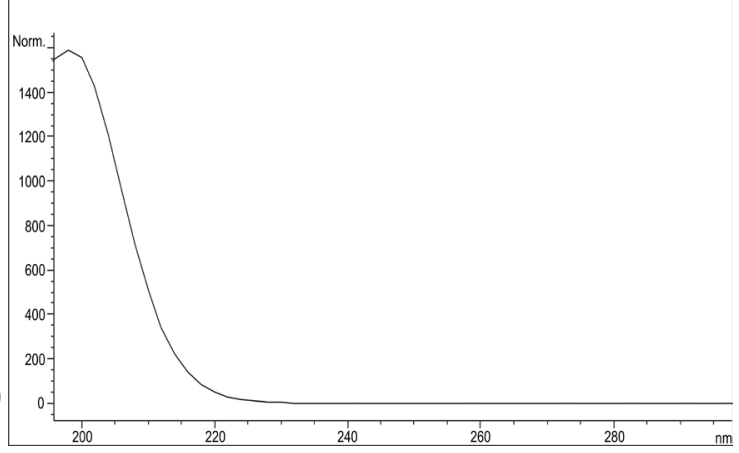

Figure 6. HPLC chromatogram of citric acid (a) and citric acid UV spectre - DAD detector (b) 


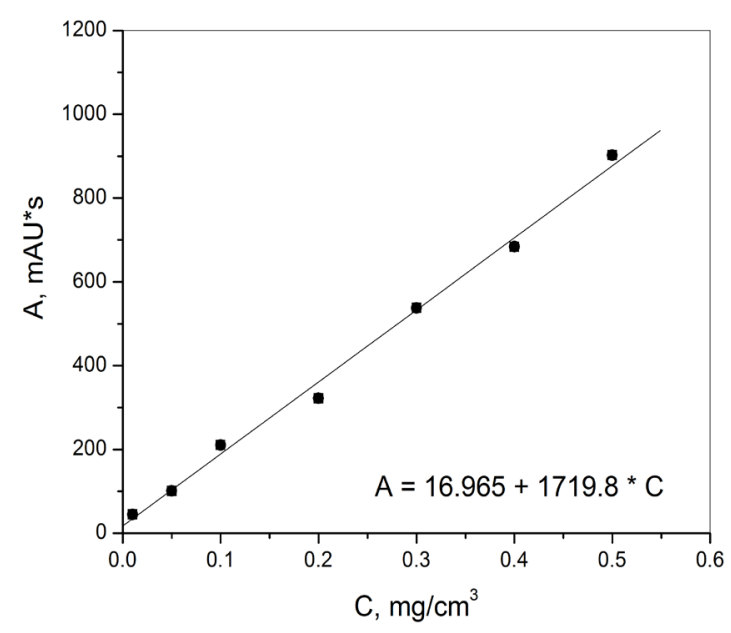

Figure 7. Calibration curve for determining citric acid

Table 2. Amounts of unreacted citric acid

\begin{tabular}{cc}
\hline Gel & Unreacted citric acid content, \% \\
\hline & \\
$\mathrm{I}_{1}$ & 9.85 \\
$\mathrm{I}_{2}$ & 9.61 \\
$\mathrm{I}_{3}$ & 13.44 \\
$\mathrm{I}_{4}$ & 14.56 \\
$I_{5}$ & 16.08 \\
$\mathrm{I}_{6}$ & 14.09 \\
\hline
\end{tabular}

(a)

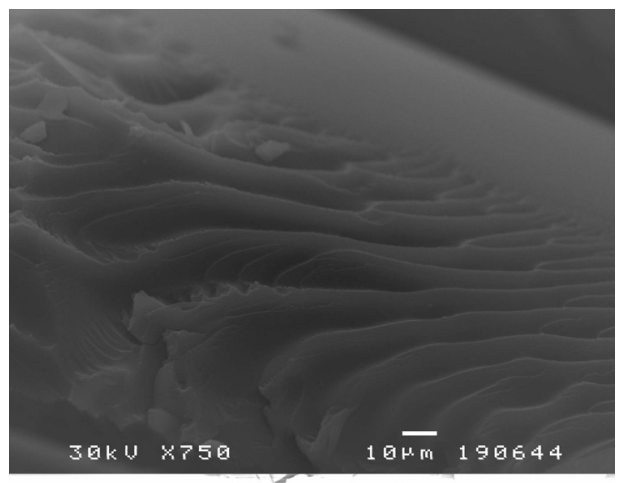

(b)

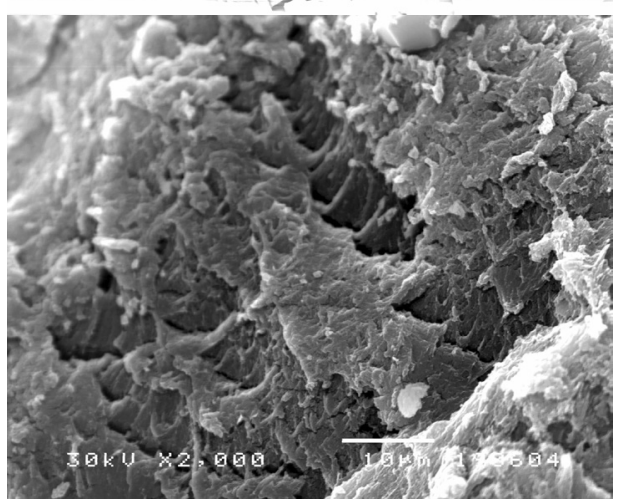

Figure 8. SEM micrography of hydrogel $\|_{4}$ samples: a) nonlyophilized b) lyophilized
The morphological characteristics of synthesised hydrogels were examined by scanning electron microscopy. Figure 8 shows SEM micrographs of non-lyophilized and lyophilized samples of hydrogel II4 which demonstrate that in the synthesised gel there are no starch granules composed of amorphic amylopectin and crystal amilose lamels, but there was crosslinking of starch with citric acid and the formation of the gel with a homogenous structure (Figure 8a). In lyophilized hydrogels (Figure $8 b)$, homogenous and porous structures are observed. Such morphology of hydrogels based on starch and citric acid indicates its potential application as a carrier of pharmacologically active substances.

(a)
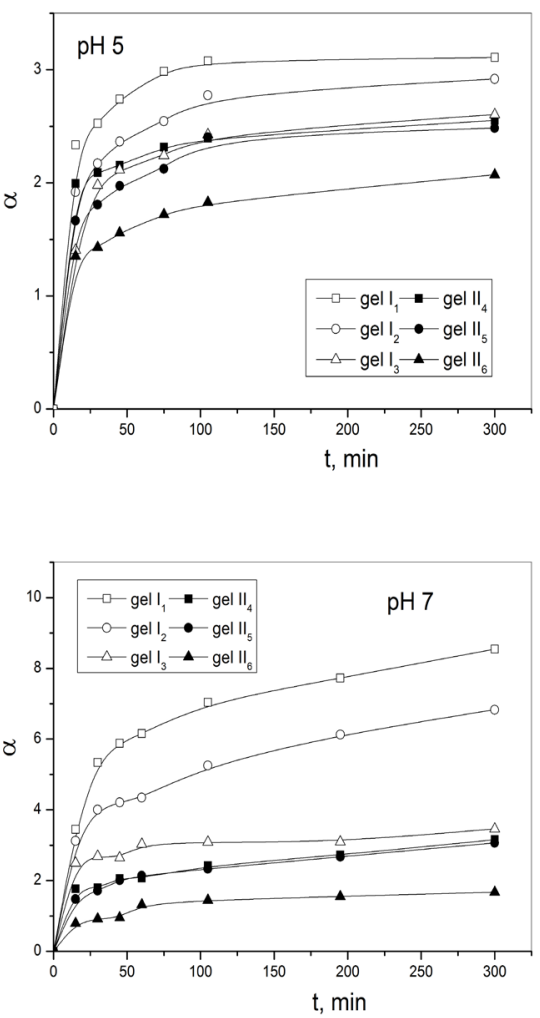

(b)



(c)

Figure 9. Dependence of the swelling degree on time for gel series I: a) in $\mathrm{pH} 5$ solution, b) in $\mathrm{pH} 7$ solution, c) in $\mathrm{pH} 9$ solution 
Figure 9 shows the dependence of the swelling degree on time for gels in the solutions with different $\mathrm{pH}$ values. The highest swelling degree is achieved by gel $\mathrm{I}_{1}$ in the solution of $\mathrm{pH}$ value 7 (Figure 9b). That is a gel produced through the synthesis from starch and citric acid whereupon the ratio of starch glucose units against the citric acid is 72 . The reaction mixture with a higher ratio of starch against citric acid did not yield any gel. With an increase in the amount of citric acid in relation to glucose units of starch, the swelling degree of hydrogels decreases. Uliniuc et al. examined the swelling degree of hydrogels based on starch and citric based hydrogels with different molar ratio of primary $\mathrm{OH}$ groups and citric acid at $37^{\circ} \mathrm{C}$. The findings of the research showed that with an increase in the citric acid content, there is a decrease in the swelling degree [16]. This means that the branches of crosslinking are shorter and the bonds between the starch chains more frequent, which is sustained on the lower values of the swelling degree. With a change in the solution $\mathrm{pH}$ in which gels swell, there is a slight change in the swelling degree. Namely, the value of the swelling degree is lower in the solutions of $\mathrm{pH}$ value of 5 and 9 (Figures $9 a$ and 9c) and there are slight differences in the swelling degrees in these solutions compared to the change in the ratio of glucose units and citric acid in gels.

Table 3. Equilibrium degree of swelling in synthesised gels based on starch and citric acid in the solutions with different $\mathrm{pH}$ values

\begin{tabular}{cccc}
\hline \multirow{2}{*}{ Gel } & \multicolumn{3}{c}{ Equilibrium degree of swelling, $\alpha$} \\
& $\mathrm{pH} \mathrm{5}$ & $\mathrm{pH} \mathrm{7}$ & $\mathrm{pH} \mathrm{9}$ \\
$\mathrm{I}_{1}$ & 3.11 & 8.55 & 4.30 \\
$\mathrm{I}_{2}$ & 2.92 & 6.83 & 4.08 \\
$\mathrm{I}_{3}$ & 2.61 & 3.46 & 3.59 \\
$\mathrm{I}_{4}$ & 2.53 & 3.16 & 3.36 \\
$\mathrm{I}_{5}$ & 2.48 & 3.07 & 3.27 \\
$\mathrm{I}_{6}$ & 2.07 & 1.67 & 2.12 \\
\hline
\end{tabular}

Table 3 shows the values of equilibrium degrees of swelling after $24 \mathrm{~h}$. The changes in swelling degrees in $\mathrm{pH} \mathrm{5,} 7$ and 9 solutions are relatively small for all synthesised gels. The swelling degree of hydrogels rises abruptly in the first $25 \mathrm{~min}$, after which the changes with the time are smaller until equilibrium is achieved. The overall observation is that there are no significant changes in equilibrium degrees of swelling with a change in $\mathrm{pH}$ value of the solutions in which swelling of hydrogels took place. This indicates that there are no free carboxyl groups in gels to a great extent, which was confirmed through the FTIR analysis. If there were free carboxyl groups in gels, the dissociation of $\mathrm{COOH}$ groups at lower $\mathrm{pH}$ values would be suppressed, while at higher $\mathrm{pH}$ values the dissociation of $\mathrm{COOH}$ would be favourised. With an increase in dissociation of these groups, there would be a significant rise in the equilibrium degree of swelling, ten times or more [25]. Since there is no rise in the equilibrium degree of swelling to a large extent with an increase in $\mathrm{pH}$ value, the conclusion can be drawn that there are no free carboxyl groups in the gel. The position of absorption bands of $\mathrm{C}=\mathrm{O}$ groups of carboxyl and ester groups also confirms this. All this indicates that the gel structure is probably like the one shown in Figure 5.

\section{Conclusion}

Two series of hydrogels based on starch and citric acid were synthesised without using any other chemicals and the chemical characterisation of synthesised hydrogels was carried out. FTIR analysis has shown that the basic synthesis reaction of polycondensation type is polyesterification. The change in the position of absorption bands of $\mathrm{C}=\mathrm{O}$ group from citric acid (1753 $\mathrm{cm}^{-1}$ and $1714 \mathrm{~cm}^{-1}$ ) indicates the esterification process of carboxyl groups of citric acid with hydroxyl groups of starch and the emergence of ester groups whose $\mathrm{C}=\mathrm{O}$ group absorbs in a frequency field of $1721-1735 \mathrm{~cm}^{-1}$. By means of HPLC method the unreacted citric acid content was analysed and the measured values show that it is within the range from 9.85 up to $16.08 \%$. With an increase in the content of citric acid as a cross-linker, the swelling degree of hydrogels drops. The highest swelling degree is 8.55 for the hydrogel with the smallest content of citric acid, $l_{1}$ (the ratio of glucose units of starch and citric acid is 72) is in water at $\mathrm{pH} 7$. Also, small differences in the values of the swelling degree at different $\mathrm{pH}$ values of the swelling solution indicate that there are no free carboxyl groups in the gel.

The synthesised polymer materials are enivronmentally friendly and fully biodegradable. Swelling of these gels does not depend significantly on the solution $\mathrm{pH}$, and thus there will not be any significant impact of potential differences in $\mathrm{pH}$ of the media of individual users. Thanks to these properties, the synthesized hydrogels can be used as carriers for the release of pharmaceutical active substances [16].

\section{Acknowledgements}

Republic of Serbia - Ministry of Education, Science and Technological Development, Program for financing scientific research work, number 451-03-68/2020$14 / 200133$.
Abbreviations and symbols
Fourier transform infrared spectroscopy, (FTIR)
High-performance liquid chromatography, (HPLC)
Hydrochloric acid, $(\mathrm{HCl})$
Sodium hydroxide, $(\mathrm{NaOH})$
Scanning electron microscopy, (SEM) 


\section{References}

[1] J. Park, Preparation and characterization of hydrogels using biopolymers, Journal of Material Sciences and Engineering, 5 (2016) 10-48.

[2] S. Van Vlierberghe, P. Dubruel, E. Schacht, Biopolymerbased hydrogels as scaffolds for tissue engineering applications: a review, Biomacromolecules, 12(5) (2011) 1387-1408.

[3] E. Caló, V. V. Khutoryanskiy, Biomedical applications of hydrogels: A review of patents and commercial products, European Polymer Journal, 65 (2015) 252-267.

[4] N. A. Peppas, P. Bures, W. Leobandung, H. Ichikawa, Hydrogels in pharmaceutical formulations, European Journal of Pharmaceutics and Biopharmaceutics, 50(1) (2000) 27-46.

[5] S. Lifeng, Z. Jin, Y. Xiaoyan, Strengthening of hydrogels based on polysaccharide and polypeptide, Progress in Chemistry, 26(2-3) (2014) 385-393.

[6] C. García-Astrain, L. Martin, M. A. Corcuera, A. Eceiza, N. Gabilondo, Innovative Systems from Clickable Biopolymer-Based Hydrogels for Drug Delivery. In Industrial Applications of Renewable Biomass Products, S.N. Goyanes, N.B. D'Accorso, Springer, Cham 2017, p. 117-133

[7] P. N. Dave, A. Gor, Natural polysaccharide-based hydrogels and nanomaterials: recent trends and their applications. In Handbook of Nanomaterials for Industrial Applications, C.M. Husein, Elsevier 2018, p. 36-66.

[8] A. Blennow, T. H. Nielsen, L. Baunsgaard, R. Mikkelsen, S. B. Engelsen, Starch phosphorylation: a new front line in starch research, Trends in plant science, 7(10) (2002) 445-450.

[9] A. Raguin, O. Ebenhöh, Design starch: stochastic modeling of starch granule biogenesis, Biochemical Society Transactions, 45(4) (2017) 885-893.

[10] N. Reddy, R. Reddy, Q. Jiang, Crosslinking biopolymers for biomedical applications, Trends in biotechnology, 33(6) (2015) 362-369.

[11] N. Reddy, Y. Li, Y. Yang, Alkali-catalyzed low temperature wet crosslinking of plant proteins using carboxylic acids, Biotechnology progress, 25(1) (2009) 139-146.

[12] N. G. Kanse, M. Deepali, P. Kiran, B. Priyanka, P. Dhanke, A Review on Citric Acid Production and Its Applications, International Journal of Current Advanced Research, 6 (2017) 5880-5883.

[13] C. Demitri, R. Del Sole, F. Scalera, A. Sannino, G. Vasapollo, A. Maffezzoli, L. Nicolais, Novel superabsorbent cellulosebased hydrogels crosslinked with citric acid, Journal of Applied Polymer Science, 110(4) (2008) 2453-2460.

[14] N. Reddy, Y. Yang, Citric acid cross-linking of starch films, Food chemistry, 118(3) (2010) 702-711.

[15] C. Menzel, E. Olsson, T. S. Plivelic, R. Andersson, C. Johansson, R. Kuktaite, K. Koch, Molecular structure of citric acid cross-linked starch films, Carbohydrate polymers, 96(1) (2013) 270-276.

[16] A. Uliniuc, T. Hamaide, M. Popa, S. Băcăiță, Modified starch-based hydrogels cross-linked with citric acid and their use as drug delivery systems for levofloxacin, Soft Materials, 11(4) (2013) 483-493.

[17] A. Hebeish, A. A. Aly, A. El-Shafei, S. Zaghloul, Synthesis and Characterization of Cationizedtarches for Application in Flocculation, Finishing and Sizing, Egyptian Journal of Chemistry, 52 (2009) 73-89.
[18] A. O. Odiongenyi, N. B. Essien, R. A. Ukpe, Corn Starch as a Substitute for Commercial Food Starch: FT-IR and Rheological Characterization, Journal of Scientific and Engineering Research, 3(6) (2016) 494-501.

[19] P. Deeyai, M. Suphantharika, R. Wongsagonsup, S. Dangtip, Characterization of modified tapioca starch in atmospheric argon plasma under diverse humidity by FTIR spectroscopy, Chinese Physics Letters, 30(1) (2013) 018103.

[20] N. T. Thuy, D. L. Minh, Size effect on the structural and magnetic properties of nanosized perovskite $\mathrm{LaFeO} 3$ prepared by different methods, Advances in Materials Science and Engineering, 2012 (2012) 1-6.

[21] Z. Cai, B. Ji, K. Yan, Q. Zhu, Investigation on Reaction Sequence and Group Site of Citric Acid with Cellulose Characterized by FTIR in Combination with TwoDimensional Correlation Spectroscopy, Polymers, 11(12) (2019) 2071.

[22] H. L. Lin, P. C. Hsu, S. Y. Lin, Theophylline-citric acid cocrystals easily induced by DSC-FTIR microspectroscopy or different storage conditions, Asian journal of pharmaceutical sciences, 8(1) (2013) 19-27.

[23] M. P. Hofmann, A. M. Young, U. Gbureck, S. N. Nazhat, J. E. Barralet, FTIR-monitoring of a fast setting brushite bone cement: effect of intermediate phases, Journal of Materials Chemistry, 16(31) (2006) 3199-3206.

[24] P. Nagaraj, A. Sasidharan, V. David, A. Sambandam, Effect of cross-linking on the performances of starchbased biopolymer as gel electrolyte for dye-sensitized solar cell applications, Polymers, 9(12) (2017) 667.

[25] A. Zdravković, Lj. Nikolić, S. Ilić-Stojanović, V. Nikolić, S. Najman, Ž. Mitić, A. Ćirić, S. Petrović, Removal of heavy metal ions from aqueous solutions by hydrogels based on $\mathrm{N}$-isopropylacrylamide and acrylic acid, Polymer Bulletin, 75(10) (2018) 4797-4821. 


\section{SINTEZA I KARAKTERIZACIJA HIDROGELOVA NA BAZI SKROBA I LIMUNSKE KISELINE}

Ljubiša Nikolić1, Tijana Stojanović ${ }^{1}$, Vesna Nikolić1, Maja Urošević1, Snežana llić-Stojanović ${ }^{1}$,Ana Tačić ${ }^{1}$, Ivana Gajić ${ }^{1}$, Vesna Savić ${ }^{2}$, Aleksandar Zdravković ${ }^{3}$

${ }^{1}$ Tehnološki fakutet, Univerzitet u Nišu, Leskovac, Srbija UDK 544.743.432:547.458.61:547.477

${ }^{2}$ Odsek za farmaciju, Medicinski fakultet, Univerzitet u Nišu, Niš, Srbija

${ }^{3}$ Akademija strukovnih studija Južna Srbija, Odsek za tehnološko umetničke studije Leskovac, Leskovac, Srbija

U ovom radu sintetisane su dve serije hidrogelova sa različitim molskim odnosom glukoznih jedinica skroba i limunske kiseline. Prednost upotrebe prirodnih sirovina (skroba i limunske kiseline) za sintezu hidrogelova proizilazi iz činjenice da su to sirovine koje se sintetišu u prirodi, korisne su za čoveka, nakon upotrebe lako podležu razgradnji i bezopasne su. Dobijeni hidrogelovi i polazni reaktanti strukturno su okarakterisani primenom metode infracrvene spektroskopije sa Furijeovom transformacijom (FTIR). FTIR analiza pokazuje da se reakcija sinteze hidrogelova na bazi skroba i limunske kiseline zasniva na reakciji esterifikacije karboksilnih grupa limunske kiseline sa hidroksilnim grupama skroba. Zaostala količina limunske kiseline u sintetisanim hidrogelovima određena je tečnom hromatografijom pod visokim pritiskom (HPLC). Vrednosti neproreagovale limunske kiseline nalaze se u opsegu 9,85 do 16,08\%. Skenirajuća elektronska mikroskopija primenjena je za analizu morfologije hidrogelova. Bubrenje hidrogelova praćeno je na $25^{\circ} \mathrm{C} u$ rastvorima $\mathrm{pH}$ vrednosti 5,7 i 9 . Najveći stepen bubrenja $(\alpha=8,55)$ dobija se u vodi na $\mathrm{pH} 7$, za hidrogel koji je sintetisan sa najmanjim sadržajem limunske kiseline kao umreživačem i to pri odnosu glukoznih jedinica skroba i limunske kiseline od 72. Sintetisani hidrogelovi od ovakvih monomera su ekološki prihvatljivi i u potpunosti biorazgradivi. 